\title{
EMERGING TECHNOLOGIES FOR WASTE TO ENERGY PRODUCTION: A GENERAL REVIEW
}

\author{
Kajal Saini*, Keshav Saini \\ E-mail Id: kajal2597@gmail.com, keshavsaini0007@gmail.com
}

\begin{abstract}
*PhD Scholar, Environmental Science Department, J.C. Bose University of Science \& Technology, YMCA, Faridabad, Haryana, India.
\end{abstract}

Junior Production Executive at GC Rieber Compact India, Gurugram, Haryana, India.

\begin{abstract}
Growing population leads to industrialisation and urbanization which in turn generate huge amount of waste that represents a big problem for many developed and developing countries. Emerging solution for this problem can be use of wastes as a sustainable source of energy in the form of heat, electricity, fertilizer and biofuel like bioethanol. Type of technology employed is mainly based on the composition of waste whether it is rich in organic matter like MSW or not. WTE technologies reduce the volume of waste as well as decrease the dependence on fossil fuels for energy generation. This study focuses on overview of various available waste to energy conversion technologies like pyrolysis, gasification, incineration, biochemical treatments like landfill gas, aerobic and anaerobic digestion of wastes.
\end{abstract}

Keywords- Gasification, Incineration, Municipal Solid Waste, Pyrolysis, WTE Technologies.

\section{INTRODUCTION}

Rapid industrialization and urbanisation has increased the generation of waste worldwide due to changes in the pattern of lifestyle compared to the past as there is an increase in demand for energy resources. Out of the total waste generated Municipal Solid Waste (MSW) has become a major area of concern worldwide. It is expected that MSW generation will double by 2025. Municipal Solid Waste includes household, industrial, commercial, construction and demolition, residential and institutional waste. Municipalities and similar entities face many problems in the disposal of MSW and associated feedstock due to improper segregation and management.Conversion of MSW to energy proves to be a sustainable management of waste. Energy from Waste (EFW) or Waste to Energy (WTE) is referred as generation of electricity or heat from the processing and treatment of waste. WTE technologies lead to less dependence on fuels, decrease the demand for dumping sites and landfills, reduce environmental pollution as well as enhance the economic viability.China is the leading nation with more than 300 running plants for WTE conversion. In India, on an average $0.5 \mathrm{Kg}$ of waste is generated by a single person per day. People with higher income generate more waste because of their power to afford and consume more goods.The Ministry of New and Renewable Energy of India is providing financial support for promoting WTE recovery and also supporting through providing incentives and subsidies.

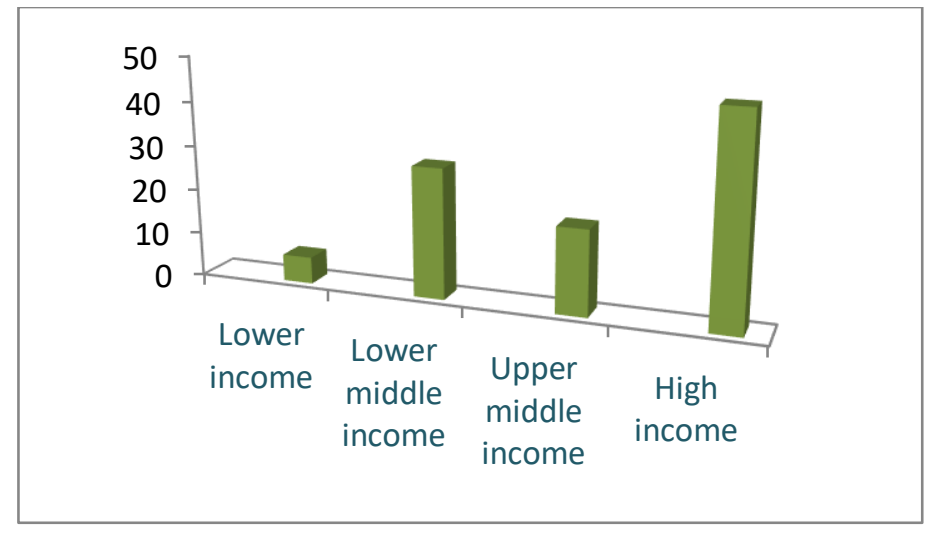

Figure 1: \% Waste generation distribution by different income groups [14]. 


\section{THERMOCHEMICAL TREATMENT OF WASTE}

\subsection{Incineration}

Incineration is defined as the process to treat waste (non-refined and crude) by oxidative combustion [1] or can say by controlled burning in an advanced engineered structure i.e. incinerator [2]. It is one of the best methods for waste management as it reduces the volume of waste by $70 \%$ to $90 \%$. Incineration of waste produces heat and energy at a temperature of minimum $800^{\circ} \mathrm{C}$ that can be used in production of electricity through steam turbines [3]. This technology is mainly practiced in the developed nations like the European Union, Japan and USA [4]. Though incineration is very efficient and simple technology, but cannot be employed on a large scale due to its high investment, operation and maintenance cost $[5,6]$.

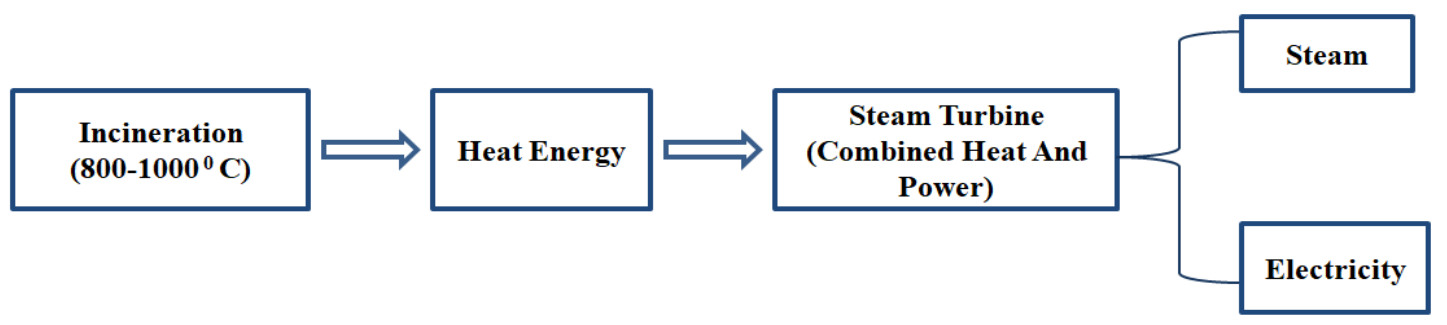

Figure 2: Treatment of waste through incineration [3].

\subsection{Gasification}

In this method of WTE, waste is acted upon by various agents like steam and oxygen at a temperature of about $500^{\circ} \mathrm{C}-$ $1800^{\circ} \mathrm{C}$ in a controlled environment to produce Syngas which is one of the energy rich gases. Syngas is also known as Synthesis gas. It is made up of carbon monoxide, hydrogen, carbon dioxide and other gases. Syngas is employed to produce electricity using gas turbines [3]. Gasification can reduce volume of waste by $90 \%$ and mass of waste by 70\% [7]. Mainly solid and semisolid waste is employed in this technology [8].

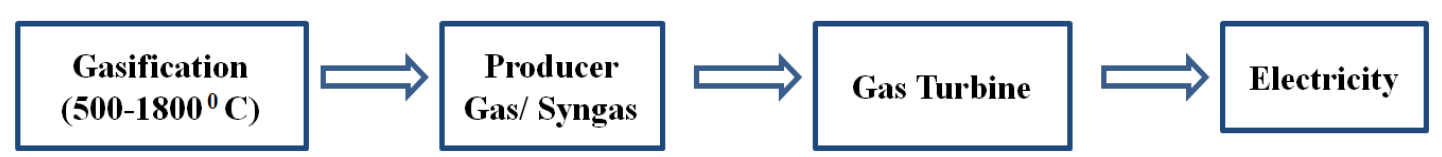

Figure 3: Treatment of waste through gasification [3].

\subsection{Pyrolysis}

Pyrolysis is a thermal or endothermic process which converts waste to more valuable products having greater calorific value than initial waste [9]. In pyrolysis, complex chain of polymer breaks into simpler or less complex chains at a temperature $500^{\circ} \mathrm{C}-800^{\circ} \mathrm{C}$ in anaerobic condition (absence of air). Depending upon the temperature, residence time, pyrolysis reactor and composition of waste three major types of products are formed namely char, oil and gas [1]. This method is mainly employed in petrochemical industries. This is the best method for handling MSW but their use is limited due to high maintenance and operation cost when employed at commercial level [10].

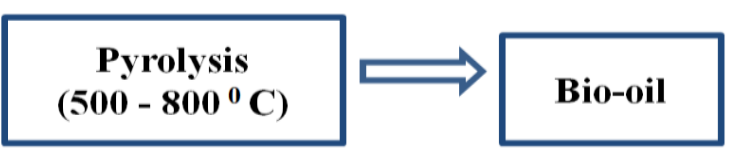

Figure 4: Treatment of waste through pyrolysis [3].

\section{BIOCHEMICAL TREATMENT OF WASTE}

\subsection{Anaerobic digestion}

Anaerobic treatment is also referred as biomethanation. In this process, anaerobic microbes act upon and digest organic rich MSW to produce biogas in the absence of air [7]. Biogas is composed of $60 \%$ methane, $39 \%$ carbon dioxide and $1 \%$ other gases like ammonia [1]. This biogas can be used in electricity production. Sites near food processing industries and dairy farm will be a potential site for setting up of biogas plant. Wastes having high cellulosic material can be used to produce 
bioethanol that can be used as an alternate fuel for petrol. Bioethanol is produced using yeasts by fermentation process. After extraction of bioethanol from the waste, the digestate obtained can be used as a fertilizer and fodder for cattle [11,12].

\subsection{Aerobic composting}

In this method, organic rich wastes decomposed by the action of aerobic microbes to produce nutrient rich compost which can be utilized as a fertilizer in agricultural fields [7].

Less space is required for treatment of waste through anaerobic than aerobic treatment [13]. Wastes having high moisture content can be treated efficiently by anaerobic digestion. Segregation of waste is required before applying biochemical treatmentas microbes do not act on non-biodegradable wastes. This treatment method is very time consuming, but it is very economical and environmentally friendly [14].

\subsection{Landfill gas}

Landfill gas is produced from the decomposition of organic waste material in unsanitary landfills. Landfill gas contains $50 \%$ methane, $45 \%$ carbon dioxide, $4 \%-5 \%$ hydrogen sulfide and $1 \%$ nitrogen. This method is not environmentally friendly as it's leachate pollute the ground water of the vicinity and also release greenhouse gases like methane and carbon dioxide in the atmosphere which can be employed to generate electricity when treated in sanitary landfills $[15,16]$.

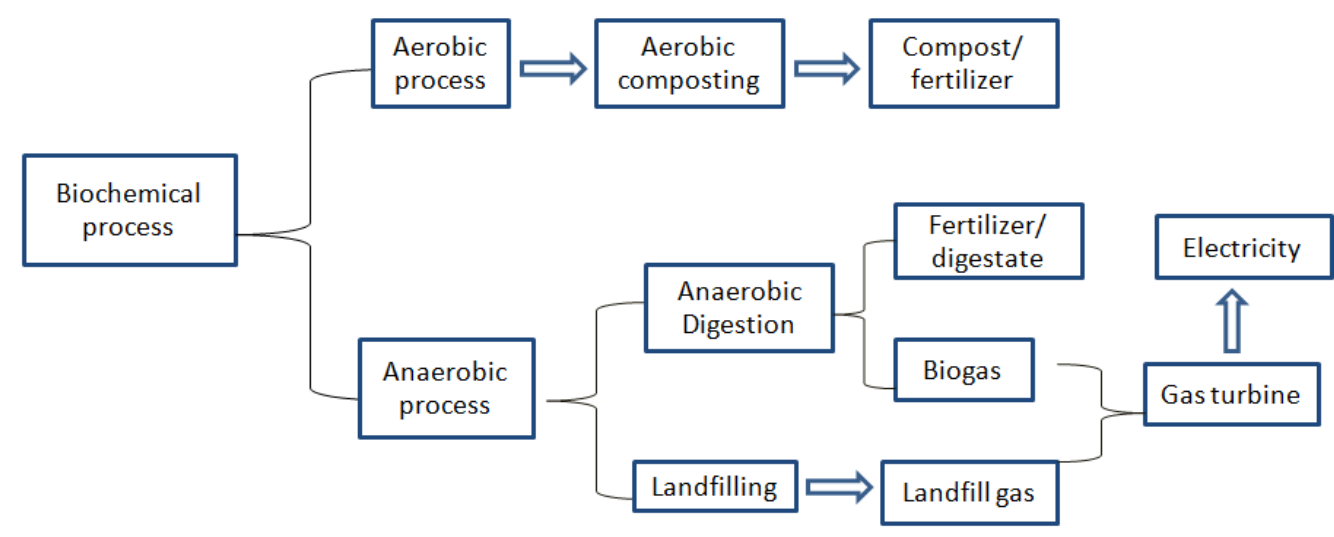

Figure 5: Biochemical treatment of waste [3].

\section{CONCLUSION}

It may be concluded from the above knowledge that efficiency of WTE technologies depends on the type of waste to be treated. Wastes having low organic and moisture can be treated efficiently through thermochemical treatment methods like incineration, pyrolysis and gasification. Anaerobic digestion can be considered to be the most beneficial method for waste treatment in developing countries. These WTE technologies are known to be environmental friendly, efficient and economical, the only need is to promote these technologies at larger scale with the support of Government subsidies, policies and regulations. There is also a need to develop sustainable waste management related awareness among the people worldwide.

\section{REFERENCES}

[1] Maisarah M., Chien Bong C. P., Ho W. S., Lim J. S., Muis Z. A., Hashim H., Elagroudy, S., Hoh Teck G. L., \& Ho C. S., "Review on the Suitability of Waste for Appropriate Waste-to- Energy Technology". Chemical Engineering Transactions, 63, 187-192, 2018.

[2] Gumisiriza R., Hawumba J.F., Okure M. and Hensel O., "Biomass waste-to-energy valorisation technologies: a review case for banana processing in Uganda", 10:11, 2017

[3] Nosherwani S.A, Nausherwani S., "A Review of Waste to Energy Technologies". Proceedings of the 6th Conference on Contemporary Problems of Power Engineering and Environmental Protection : Gliwice, Poland. 2018

[4] Scarlat N., Motola V., Dallemand J.F., Monforti-Ferrario F., Linus M., "Evaluation of energy potential of municipal solid waste from African Urban areas". Renew Sustain Energy Rev.;50:1269-86, 2015. 
[5] UNEP. Municipal solid waste: is it garbage or gold? UNEP Global Environmental Alert Series; 2013.

[6] UN-HABITAT. Collection of municipal solid waste in developing countries. Nairobi: United Nations Human Settlements Programme (UN-HABI-TAT); 2010.

[7] Gupta M., Srivastava M., Agrahari S.K. and Detwal P. "Waste to energy technologies in India: A review". Journal of Energy and Environmental Sustainability, 6, 29-35, 2018.

[8] El-Sheltawy S.T. , Al-Sakkari E.G., Fouad M. "Waste to Energy Trends and Prospects: A Review”, 2016.

[9] Basu P., "Biomass gasification and pyrolysis: practical design and theory" Elsevier Inc., USA, ISBN 978-0-12374988-8, 2010.

[10] L. Giusti, “A review of waste management practices and their impact on human health", Waste Management, vol.8, pp. 2227-2239,2009.

[11] Luque R., Lin C. S. K., Wilson K. and Clark J. "Handbook of Biofuels Production: Second Edition ", Woodhead Publishing, ISBN 9780081004555, Cambridge, UK, 2016.

[12] Vij S., " Biogas production from kitchen waste: A Seminar Report submitted in partial fulfillment of the requirements for Bachelor of Technology (Biotechnology)" National Institute of Technology, Rourkela, 2011.

[13] Finnveden G., Johansson J., Lind P., "Life cycle assessment of energy from solid waste" part 1: general methodology and results. J Clean Prod.13:213-229, 2005.

[14] Rafey A., Prabhat K., Samar M., “Comparison of Technologies to Serve Waste to Energy Conversion”. Int J Waste Resour ,10:372, 2020.

[15] Kumar A., Samadder S.R., "A review on technological options of waste to energy for effective management of municipal solid waste", Waste Management. 69, 407-422, 2017.

[16] Ogunjuyigbe A.S.O., Ayodele T.R., Alao M.A., "Electricity generation from municipal solid waste in some selected cities of Nigeria: An assessment of feasibility, potential and technologies". Renewable and Sustainable Energy Reviews, Vol. 80, 149-162, 2017. 